\title{
3. QUATERNARY VERTICAL TECTONICS OF THE CENTRAL NEW HEBRIDES ISLAND ARC1
}

\author{
Frederick W. Taylor ${ }^{2}$
}

\begin{abstract}
Hundreds of meters of uplift of both the frontal arc and backarc characterize the late Quaternary vertical tectonic history of the central New Hebrides Island Arc. This vertical deformation is directly related to large, shallow earthquakes on the interplate thrust zone postulated on the basis of coral emergence data. This chapter presents evidence from the best documented and illustrated examples of uplifted coral reefs from the central New Hebrides Island Arc for the pattern and rates of vertical deformation caused by subduction of the d'Entrecasteaux Zone and the West Torres Massif over the past few 100 k.y. The pattern of vertical movement based on upper Quaternary coral reef terraces documents that the islands of Espiritu Santo, Malakula, Pentecost, and Maewo have risen hundreds of meters during the late Quaternary. This history suggests that the present pattern and rates of vertical deformation should be extrapolated back to at least $1 \mathrm{Ma}$, which would indicate that the total amount of structural and morphological modification of the arc during the present phase of deformation is more significant than previously assumed. The morphology of the central New Hebrides Island Arc may have resembled a more typical arc-trench area only 1-2 Ma. If the late Quaternary patterns and rates of vertical deformation have affected the central New Hebrides Island Arc since 1-2 Ma, then virtually all of the anomalous morphology that characterizes the central New Hebrides Island Arc can be attributed to the subduction of the d'Entrecasteaux Zone and the West Torres Massif.
\end{abstract}

\section{INTRODUCTION}

The central New Hebrides Island Arc (Vanuatu) is characterized by anomalous morphology and island geography (e.g., Collot et al., 1985) and rapid vertical tectonic movements (Neef and Veeh, 1977; Taylor et al., 1980, 1985, 1987; Jouannic et al., 1980, 1982; Carney and Macfarlane, 1982; Macfarlane et al., 1988). The unusual morphology includes the absence of a physiographic trench west of Espiritu Santo and Malakula islands, the presence of highly emerged islands very near the convergent plate boundary, emerged islands in the backarc and forearc, and Aoba Basin approximately centered on the volcanic arc (Fig. 1). I consider the evidence for the late Quaternary (since $\sim 500,000$ yr before present, or $500 \mathrm{Ka}$ ) pattern and rates of vertical deformation and propose that most of the anomalous morphology could be explained if present-day patterns and rates existed since 1-2 Ma. However, data required to test this hypothesis are not yet available.

Recent studies have proposed that the anomalous morphology of the central New Hebrides Island Arc is the result of the subduction of two bathymetric features: the d'Entrecasteaux Zone (DEZ) and the West Torres Massif (WTM) (Fig. 1) (e.g., Ravenne et al., 1977; Pascal et al., 1978; Chung and Kanamori, 1978; Taylor et al., 1980, 1985; Collot et al., 1985; Marthelot et al., 1985; Louat et al., 1988). The following phenomena have been attributed to the subduction of these features: (1) very rapid uplift of the frontal arc of the central New Hebrides, (2) shift of the axis of uplift from western Espiritu Santo and Malakula islands to the west, very close to the convergent plate boundary, (3) uplift of the backarc islands of Maewo and Pentecost, (4) subsidence of the volcanic chain and formation of the contemporary Aoba Basin, and (5) modification of the Wadati-Benioff zone dipping east-

\footnotetext{
${ }^{1}$ Collot, J.-Y., Greene, H. G., Stokking, L. B., et al., 1992. Proc. ODP, Init. Repts., 134: College Station, TX (Ocean Drilling Program).

2 Institute for Geophysics, The University of Texas at Austin, 8701 MoPac Boulevard, Austin, TX 78759-8345, U.S.A.
}

ward beneath the central New Hebrides Island Arc. Subduction of topographic features on the downgoing plate potentially imposes major structural and morphological modifications on an island arc. This rapid deformation may exemplify a relatively short-lived but important episode in arc system evolution in comparison with long episodes of subduction accompanied by much slower vertical tectonism.

The fastest uplift documented in the central New Hebrides Island Arc occurs along the north-northwest-south-southeast topographic axis of western Espiritu Santo Island. Where this axis intersects the south coast, the island has risen at a minimum mean rate of $6 \mathrm{~mm} / \mathrm{yr}$ for at least the past 12,000 yr (or 12 k.y.) (Taylor et al., 1987, and unpubl. data). During the preceding 125 k.y., uplift rates were largely uniform at any given place, but only about $50 \%$ as fast as recorded by the most recent $12 \mathrm{k}$.y. of reef deposition (Jouannic et al., 1980; Taylor et al., 1985, 1987; Urmos, 1985; Bloom and Yonekura, 1985).

It is not clear whether all of the anomalous morphology is the result of subduction of the WTM and DEZ or if the area was already anomalous to some extent when subduction of these features began. The precise extent of the effects is a subject of interpretation of the geologic structure and stratigraphy of the central New Hebrides islands. However, it is important to determine how much of the anomalous morphology is the result of subduction of the WTM and DEZ for a realistic concept of the role of ridge subduction in arc evolution to be achieved. This paper presents evidence from uplifted coral reefs for the pattern and rates of vertical deformation caused by subduction of the WTM and DEZ over the past few 100 k.y. This deformation pattern closely matches the topography of the central New Hebrides Island Arc and suggests that it should be extrapolated backward in time to perhaps $1 \mathrm{Ma}$. It would be an interesting coincidence if subduction of the DEZ and WTM imposed a tectonic pattern identical to that left over from some completely unrelated tectonic event. If the late Quaternary pattern and rates of vertical deformation affected the central New Hebrides Island Arc since 1-2 Ma, then virtually all of the anomalous mor- 


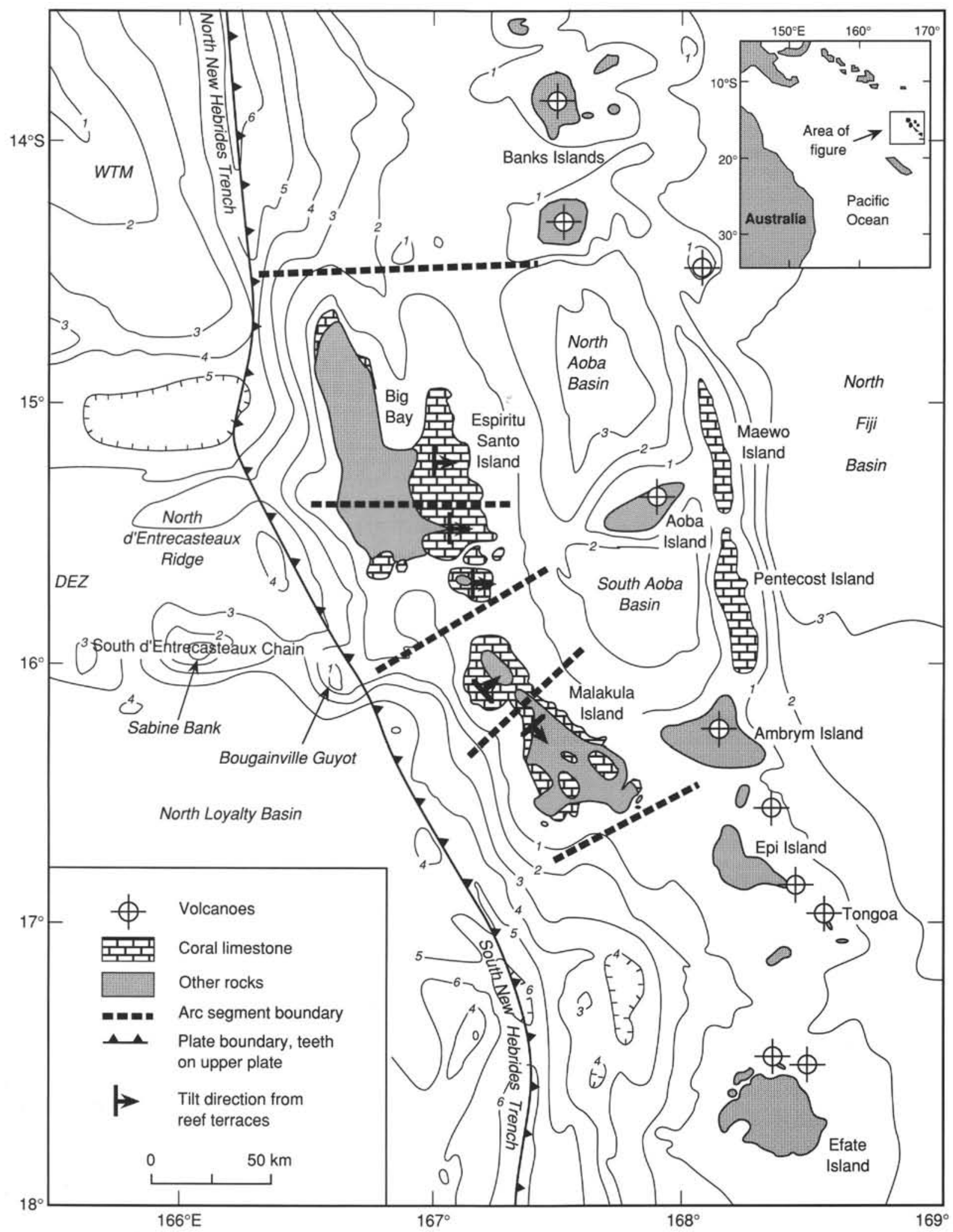

Figure 1. Map of the central New Hebrides Island Arc (after Collot and Fisher, 1988). Note location of the d'Entrecasteaux Zone (DEZ), West Torres Massif (WTM), volcanic arc islands of Aoba and Ambrym, frontal arc islands of Espiritu Santo and Malakula, and backarc islands of Maewo and Pentecost. The frontal arc is divided into four arc segments on the basis of tilt directions from uplifted coral reef terrace surfaces, uplift rates, and seismic rupture zone boundaries. All of the boundaries except the one that crosses Espiritu Santo Island appear to correspond to cross-arc fractures identified by Greene et al. (1988) from marine geophysical data. Bathymetric contour interval is $1 \mathrm{~km}$. 
phology of this part of the arc can be attributed to subduction of the WTM and DEZ and the coincidence of a pre-existing anomalous morphology is not required.

\section{PRINCIPLES}

A review of the Pliocene tectonic history drawn mainly from the synthesis of Macfarlane et al. (1988) is necessary. The ages and depositional environments of sedimentary units on which this synthesis is based are critical to interpretation of the timing of their deposition and subsequent history, including the initiation of tectonic effects of subduction of the DEZ and WTM. However, the past few 100 k.y. are emphasized because data from coral reefs can be used to document the geographic distribution and rates of vertical tectonism. Furthermore, data from this time interval are used as a model for the interpretation of events that occurred during the late Pliocene and early Quaternary, an interval for which detailed information is lacking.

The use of coral reefs as indicators of vertical tectonism is well established (e.g., Bloom et al., 1974; Jouannic et al., 1980; Taylor et al., 1980) and considerable work has been done on the emerged coral reefs of the central New Hebrides Island Arc. As a first-order approximation, the presence of young emerged coral limestone as the uppermost stratigraphic unit signifies tectonic uplift and its absence signifies stability or subsidence. Geomorphic terraces on the central Vanuatu islands result from the interaction of sea-level change, uplift, and coral reef growth. Each coral reef terrace records a specific, relatively short-lived paleo-sea-level highstand. We assume that each terrace initially formed as a level surface at sea level; therefore, deviations of each terrace from a level surface indicate subsequent deformation and tilting. Ages of fossil corals were determined by uranium-series and radiocarbon methods. Thus, at any point along each dated reef terrace, it is possible to calculate uplift as well as tilt rates and direction. Evidence from several of the best documented and illustrative examples of emerged coral reefs of the central New Hebrides Island Arc are summarized in the subsequent section.

\section{VERTICAL TECTONIC HISTORY}

The occurrence of upper Quaternary emerged coral limestone documents that the islands of Espiritu Santo, Malakula, Pentecost, and Maewo have risen by hundreds of meters during the late Quaternary (Fig. 1). In contrast, along the volcanic chain, the islands of Ambrym and Aoba have no emerged coral limestone or other evidence of ongoing uplift (Taylor et al., 1987). Isotopic ages indicate that the volcanic islands of the North and South Aoba basins have existed at least since early Pleistocene time (Mallick and Ash, 1975). The Aoba Basin, as well as the islands, has undergone net subsidence during the Quaternary, although the rates and amounts are unknown.

Both the frontal and backarc islands of the central New Hebrides Island Arc rose during the Quaternary and at least the latest phase of their uplift may have occurred simultaneously. However, the timing and rates of uplift differ from area to area on Espiritu Santo and Malakula islands. Taylor et al. (1980) subdivided Espiritu Santo and Malakula islands into four arc segments (Fig. 1), each with a different uplift and tilting history. Boundaries between segments are important rupture zone boundaries or barriers to seismic rupture propagation (e.g., Ebel, 1980; Isacks et al., 1981). Uplift histories may differ between Maewo and Pentecost islands and between the frontal and backarcs; prior to Leg 134, information was insufficient to resolve these questions.

\section{Malakula Island}

The late Pliocene to early Quaternary history of Malakula Island is represented by the Malua Formation of northern Malakula and the Wintua Formation of southern Malakula. These units were thought to be of approximately the same age (Mitchell, 1971; Macfarlane et al., 1988) because both record a late Pliocene to Pleistocene marine transgression followed by a regression, which deposited the overlying coral limestones (Macfarlane et al., 1988). However, Mitchell (1966, 1971) recognized that the Wintua Formation may be older than the Malua Formation. There are no biostratigraphic ages for the Malua Formation and microfossils from the Wintua Formation indicate either Pliocene or Quaternary ages (Mitchell, 1966 , p. 22). The coral limestone conformably overlies the Wintua Formation and sometimes unconformably overlies the Malua Formation. The uplift histories of northern and southern Malakula indicate that the Wintua Formation is older than the Malua Formation.

The Quaternary uplift histories of northern and southern Malakula Island are quite different, as revealed by their partial cappings of coral reef limestone. All of the coral limestone on northern Malakula Island (maximum altitude $=614 \mathrm{~m}$ ) emerged during the ongoing phase of uplift, estimated to have begun at least $300 \mathrm{Ka}$ to $400 \mathrm{Ka}$ on the basis of uplift rates from the last interglacial $(125 \mathrm{Ka})$ coral reef terrace (Taylor et al., 1987) (Figs. 2 and 3). In contrast, late Pliocene or early to middle Quaternary uplift in southern Malakula Island may have raised coral limestone to altitudes as great as 879 meters above sea level (masl). A cessation or reorganization of the pattern of uplift occurred with a possible time gap of unknown duration between uplift of the higher level coral limestones and the lower coral limestones on southern Malakula Island (Taylor et al., 1987). Mitchell (1966) reported Pliocene or Quaternary biostratigraphic ages for the higher (plateau) coral limestones on southern Malakula Island. During the late Quaternary, renewed vertical tectonism with uplift rates locally as great as $2.7 \mathrm{~mm} / \mathrm{yr}$ affected some areas, whereas other areas have subsided (Fig. 2). Southern Malakula Island is not tilting as a coherent block. In contrast, northern Malakula Island has emerged more than $600 \mathrm{~m}$ during a late Quaternary episode of uplift, its mean uplift rates are significantly faster than on southern Malakula Island, and no area is subsiding.

\section{Northern Malakula Island}

Northern Malakula Island is capped by coral reef limestone with a central window of exposed Miocene rocks (Figs. 2 and 3). The trends of coral reef terraces clearly reveal that this area was a paleo-island around which the reefs began to form (Jouannic et al., 1980; Taylor et al., 1980). The oldest coral reef limestone on northern Malakula Island laps onto the western side of this paleo-island and reaches a maximum altitude of about 400 masl. The absence of coral reef limestone remnants in the Miocene window suggests that the area was not rising prior to emergence of the coral reef terraces. The trends of coral reef terraces extending to the west show that terrace altitudes and uplift rates increase linearly westward until they reach the northwest-southeast-trending axis of most rapid uplift where coral limestone reaches as high as $614 \mathrm{~m}$ (Figs. 2 and 3). This is the highest elevation on northern Malakula Island and documents at least $614 \mathrm{~m}$ of late Quaternary uplift.

The lower six coral reef terraces of northern Malakula Island range in age from 0 to $125 \mathrm{Ka}$. These reefs reach a maximum altitude of about 250 to $300 \mathrm{~m}$ on the southwestern part of northern Malakula Island, indicating that the uplift rate ranged from about $0.5 \mathrm{~mm} / \mathrm{yr}$ on the northeast coast to a 


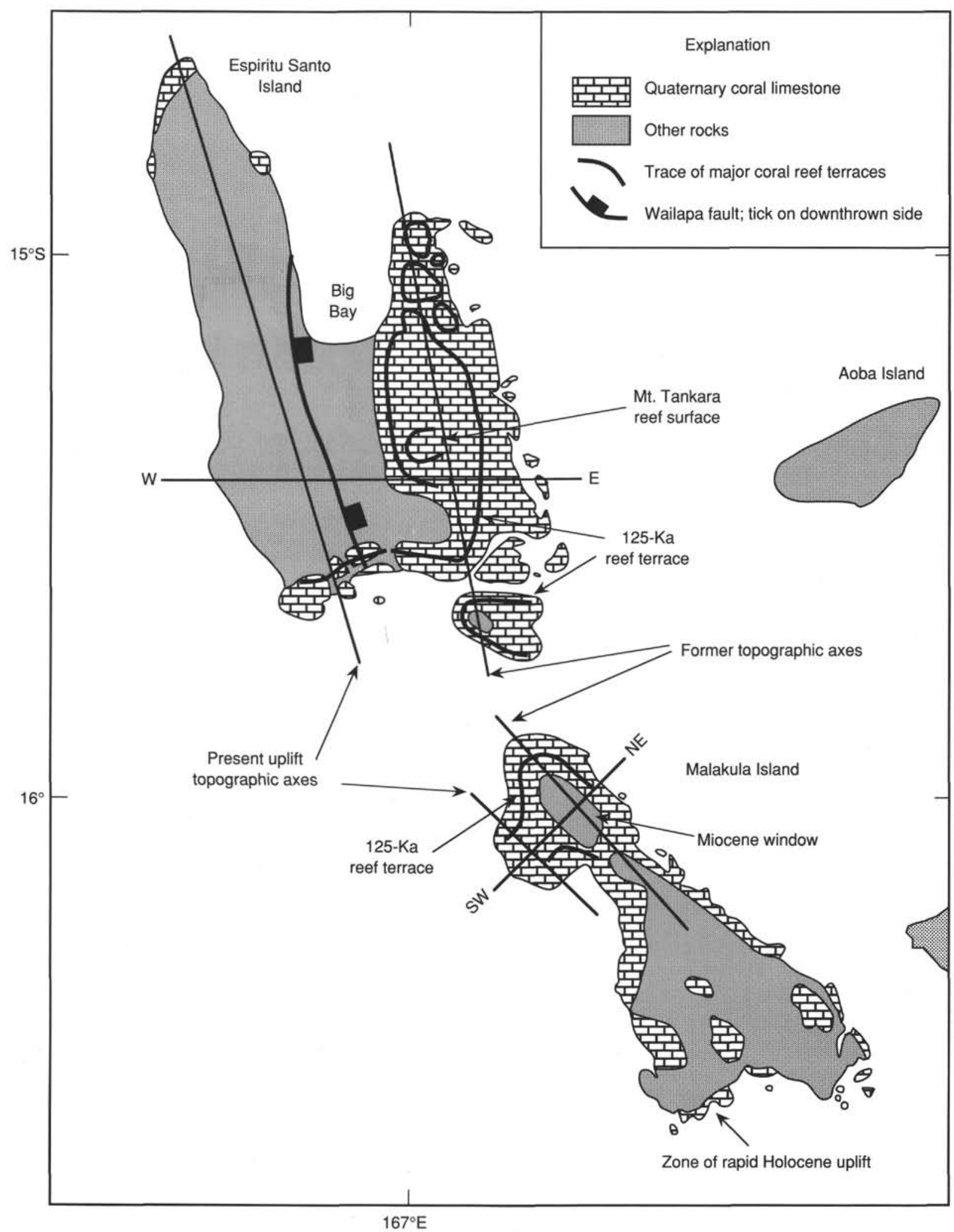

Figure 2. Map showing the distribution of coral limestone on the frontal-arc islands of Espiritu Santo and Malakula, the north-south Wailapa fault on Espiritu Santo Island, the former and present topographic axes, and the locations of the 125-Ka coral reef terrace. Note also the plateau area of the Mount Tankara surface on eastern Espiritu Santo Island. The Holocene reef terrace is not shown on this map, but it is present along nearly all of the coast line of both islands except for much of the west coast of Espiritu Santo Island. See Figures 3 and 4 for the topographic profiles across Espiritu Santo (west-east) and Malakula (southwest-northeast) islands indicated on this figure. 


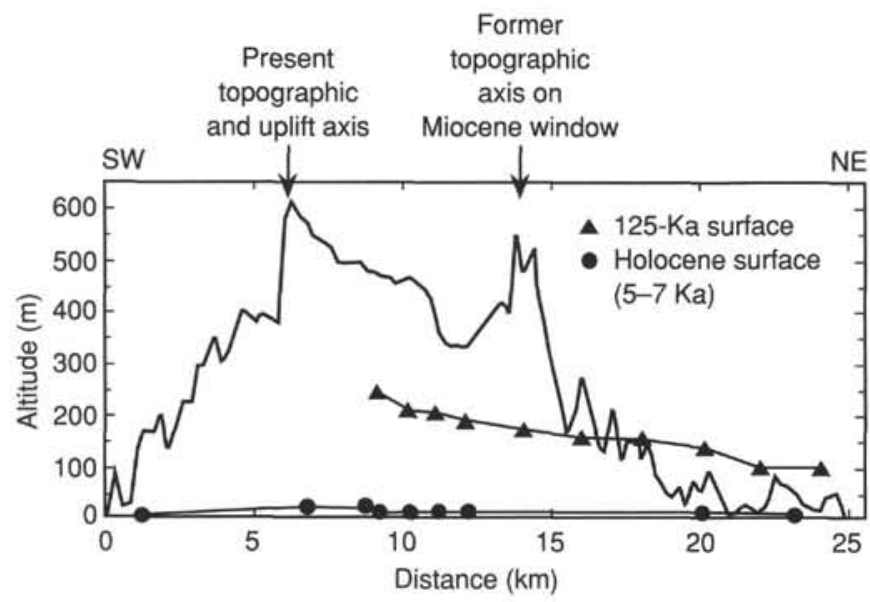

Figure 3. Topographic profile oriented southwest-northeast across northern Malakula Island. Heights of the $125-\mathrm{Ka}$ (last interglacial) and Holocene reef terraces are projected onto the profile and indicate that the uplift rate increases southwest toward the present axis of maximum uplift rate. Vertical exaggeration is $18: 1$. At the uplift rate indicated by the $125-\mathrm{Ka}$ terrace, all of northern Malakula Island could have emerged above present sea level during the past 300-400 Ka. Note that even though the present highest point is on the present topographic axis, the former topographic axis must have emerged above sea level first. The tilt rate from the 125 -Ka reef terrace is about $0.1 \mu \mathrm{R} / \mathrm{yr}$. The Holocene emergence of the past 5-7 Ka confirms that the pattern of uplift shown by the 125 -Ka terrace continues, but at a more rapid rate.

maximum of about $2 \mathrm{~mm} / \mathrm{yr}$ (Jouannic et al., 1980; Taylor et al., 1980).

At the rates documented for the past 125 k.y., $614 \mathrm{~m}$ of uplift would require only 300 to $400 \mathrm{k} . \mathrm{y}$. The distribution of emergence recorded by the Holocene reef and by a coseismic uplift in $1965\left(\mathrm{M}_{\mathrm{s}}=7.5\right)$ confirms continuation of this uplift pattern (Taylor et al., 1980). However, the amount of Holocene emergence indicates that the uplift rate has increased by approximately $50 \%$ to about $3.2 \mathrm{~mm} / \mathrm{yr}$. At this rate, the highest levels of northern Malakula Island would have begun to emerge only $200 \mathrm{Ka}$.

The Miocene window was previously located on the topographic axis (Figs. 2 and 3 ) and perhaps was the axis of fastest uplift for northern Malakula Island. Approximately $500 \mathrm{Ka}$, the axis shifted $10 \mathrm{~km}$ southwestward. The Miocene window was the first part of northern Malakula Island to emerge and has uplifted at least $400 \mathrm{~m}$ since then. However, its highest present elevation of 589 masl is lower than the maximum of 614 masl on the present uplift axis, which started from below sea level and attained a higher elevation than the Miocene window because of the southwestward shift of the uplift axis.

Differential uplift rates on northern Malakula Island have imposed a downward tilt to northeast at a mean rate of about 0.1 microRadian per year $(\mu \mathrm{R} / \mathrm{yr})$ as determined from the 125-k.y. reef terrace. The tilt rate for the Holocene terrace alone is about $50 \%$ more rapid. The boundary between northern and southern Malakula Island is clearly delineated by a drainage divide and by a discontinuity in the direction of tilting of terraces across the neck connecting northern and southern Malakula Island (Taylor et al., 1980) (Fig. 1). Reef terraces traced along the southwest coast rise gently from northern to southern Malakula Island until they intersect the tilt discontinuity. From this point, where the late Quaternary uplift rate is about $1 \mathrm{~mm} / \mathrm{yr}$, the terraces lose altitude and indicate down- ward tilting to the southeast. Uplift rates decrease to $0 \mathrm{~mm} / \mathrm{yr}$ about $15 \mathrm{~km}$ south of the boundary.

\section{Southern Malakula Island}

Coral reef limestone on southern Malakula Island appears to indicate two distinct episodes of uplift separated either by a cessation of uplift or a reorganization of the geographic distribution and rate of uplift. This change occurred sometime before the Holocene, but the timing is poorly constrained (Taylor et al., 1987).

The older uplift is recorded by coral limestone extending to the highest point on Malakula of 879 masl (Mitchell, 1966). Patches of this older coral limestone also occur at lower elevations, but sometimes in areas where the trends of younger terraces and the absence of emerged Holocene coral reef limestone show that net uplift has ceased to accumulate or subsidence has replaced uplift. The distribution of the older coral limestone patches indicates that either coral limestone did not completely cover southern Malakula as it emerged, or erosion removed much of the original coral cap.

However, one area of southern Malakula is uplifting quite rapidly (Fig. 2). The diameter of the uplifting area is approximately $20 \mathrm{~km}$ and may include an area offshore to the south. The Holocene reef reaches an altitude of about $16 \mathrm{~m}$ and indicates a mean Holocene uplift rate of at least $2.7 \mathrm{~mm} / \mathrm{yr}$ (Taylor et al., 1990). The coral limestone is continuous to approximately 85 masl and suggests that rapid uplift of this part of the south coast began before the Holocene. This area also coincides with a concentration of small earthquakes (Chatelain et al., 1986), suggesting that the uplift and underlying seismicity are related.

\section{Espiritu Santo Island}

Quaternary uplift of Espiritu Santo Island was preceded by late Pliocene transgression and deposition of the Tawoli Formation onto a subsiding Espiritu Santo Island landmass (Macfarlane et al., 1988). The Tawoli Formation consists of carbonate sands and muds deposited at water depths of at least $700 \mathrm{~m}$ (Paltech, 1979). The Tawoli stratigraphy implies that both western and central eastern Espiritu Santo Island were above sea level during the latest Pliocene. This emergence produced a marine regression that deposited the shallow-marine and fluvial Sale Formation. A marine transgression occurred on eastern Espiritu Santo Island during the Quaternary, which was followed by regression and deposition of Quaternary coral reef limestone accompanied by deposition of the Navaka Sands Formation.

Mallick and Greenbaum (1977a) proposed that western Espiritu Santo Island and the highest part of southeast Espiritu Santo Island had already emerged during the late Pliocene. In particular, late Pliocene or early Quaternary transgression submerged most of eastern and southern Espiritu Santo Island. Subsequently, eastern-but not western-Espiritu Santo Island rose several hundred meters during the Quaternary, depositing a cap of coral limestone on the emerging shoreline. Western Espiritu Santo Island decoupled from the eastern part of the island along the north-south-trending Wailapa Fault (Fig. 2). Presumably, in this scenario the recoupling of western to eastern Espiritu Santo Island occurred during the latest Quaternary, joining the final few hundred meters of uplift of eastern Espiritu Santo Island.

Most coral reef terraces on Espiritu Santo Island occur on the eastern half of the island (Fig. 2). Coral reef terrace altitudes increase westward from the east coast to a maximum altitude of $784 \mathrm{~m}$ at Mount Tankara near the center of the island. Rather than continuing to slope upward farther west, the coral cap ends abruptly in a series of terraces descending 
into the central valley of Espiritu Santo Island. This valley was a seaway between eastern and western Espiritu Santo which has gradually emptied during the last few hundred meters of emergence. Big Bay is the remnant of this seaway (Figs. 1 and 2).

All of the coral reef terraces on Espiritu Santo Island indicate downward tilting to the east and uplift rates increasing toward the topographic axis of western Espiritu Santo Island (Figs. 2 and 4). The tilt rate from the Luganville Surface (125-Ka terrace) is 0.045 to $0.80 \mu \mathrm{R} / \mathrm{yr}$ (Gilpin, 1982, p. 106). Westward from the topographic axis of western Espiritu Santo Island, the Holocene terrace rapidly decreases in height across a series of nearly vertical (apparently normal) faults. The Holocene uplift rate decreases from about $6 \mathrm{~mm} / \mathrm{yr}$ at the topographic axis to nearly 0 $\mathrm{mm} / \mathrm{yr}$ at the western limit of coral limestone (Jouannic et al., 1980; Taylor et al., 1987). Uplift rates on the axis of western Espiritu Santo Island are at least twice as fast as anywhere else on eastern Espiritu Santo. Thus, a terrace of a given age in the east occurs at approximately twice the altitude in the west.

However, reef terraces extending continuously from the eastern to western part of Espiritu Santo Island occur only across the south coast and include only the lower third of all the eastern terraces. For example, the Luganville surface (125 $\mathrm{Ka}$ ) occurs at a height of 200 masl on southeast Espiritu Santo Island, but rises to a height of about 400 masl on southwest Espiritu Santo Island (Gilpin, 1982, p. 106). Where the coral reef terraces cross the Wailapa Fault, which separates eastern and western Espiritu Santo, they are slightly displaced down to the east (see map in Mallick and Greenbaum, 1977b). This is opposite to the displacement suggested by Mallick and Greenbaum (1977a), which would allow eastern Espiritu Santo Island to uplift hundreds of meters more than western Espiritu Santo Island.

Taylor et al. (1980) identified a tilt discontinuity from the height variations of reef terraces on eastern Espiritu Santo Island (see Gilpin, 1982). The discontinuity trends east-west and is roughly aligned with the northern flank of the DEZ, with the highest peak on western Espiritu Santo Island (Tabwemesana = $1879 \mathrm{~m}$ ), and with a seismic rupture boundary (Pascal et al., 1978; Taylor et al., 1980, 1987; Ebel, 1980) (Fig. 4).

Based on the dual topographic axes of eastern and western Espiritu Santo Island and the coincidence of the axis of maximum uplift rate with the western topographic axis, Taylor et al. (1985) proposed a $25-\mathrm{km}$ westward shift of the uplift axis (Figs. 2 and 4). This shift corresponds to the southwest shift of the uplift and topographic axis of northern Malakula Island (Figs. 2 and 3). The eastern topographic axis is equivalent in location to the coral-capped Torres Islands in the northern part of the frontal arc $(\sim 60-70 \mathrm{~km}$ from the trench and $\sim 90 \mathrm{~km}$ from the volcanic arc) (Taylor et al., 1985). Sometime during the Quaternary, a new axis of more rapid uplift formed beneath western Espiritu Santo Island. The new western axis rose twice as fast as the eastern one and rapidly overtook the formerly dominant eastern axis. Consequently, western Espiritu Santo Island is topographically dominant and continues to uplift about twice as fast as the eastern topographic axis. There is no evidence that uplift of the eastern topographic axis occurred prior to the uplift of the western axis, but it is clear that initiation of the western uplift caused the western axis to become dominant. However, it is unclear whether western Espiritu Santo Island consisted of an inner trench slope similar to that located north of Espiritu Santo (Taylor et al., 1985) or whether there was already an emerged or slightly submerged ridge at the location of western Espiritu Santo.

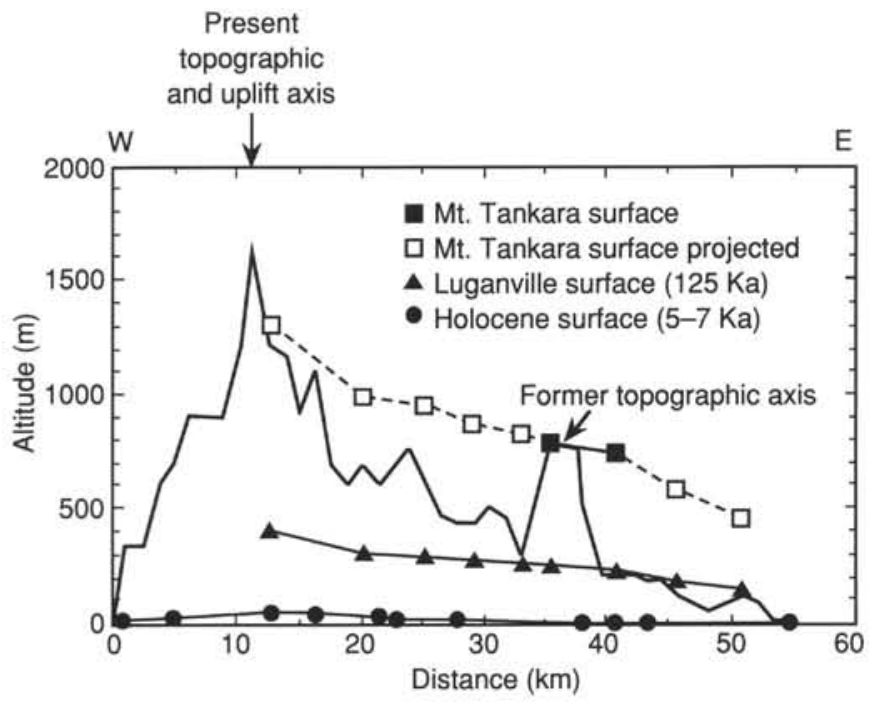

Figure 4. West-east topographic profile across Espiritu Santo Island. The uplifted $125-\mathrm{Ka}$ and Holocene terrace surfaces are projected onto the profile. Vertical exaggeration is $20: 1$. At the uplift rates indicated by the $125-\mathrm{Ka}$ reef, all of western Espiritu Santo Island could have risen from below present sea level since only $400-500 \mathrm{Ka}$. The Mount Tankara reef surface exists only on eastern Espiritu Santo Island at 783 meters above sea level (masl), but it indicates the minimum amount of uplift on eastern Espiritu Santo Island. If the mean uplift rate of the $125-\mathrm{Ka}$ reef terrace is projected back in time, then the Mount Tankara reef was at present sea level at only about $300 \mathrm{Ka}$. At the uplift rate of the 125-Ka reef, the Mount Tankara shoreline would occur at about 1400 masl on western Espiritu Santo Island. The absence of evidence for this reef surface on western Espiritu Santo Island can be attributed to the extremely rapid uplift, the absence of a suitable gently sloping substrate, and high sedimentation rates on western Espiritu Santo Island at the time.

\section{Aoba and Ambrym Islands}

Evidence of the oldest volcanism on these islands is early Pleistocene in age (Mallick and Ash, 1975). Neither island possesses emerged coral limestone (Fig. 1). Therefore, neither island is uplifting; both are probably subsiding. Taylor et al. (1987) reported evidence of contemporary submergence on Aoba Island. These volcanic edifices were built upward by subaerial ash falls and lava flows and kept pace with ongoing subsidence of the Aoba Basin. However, we have no means to estimate accurately the amount of subsidence of the Aoba Basin during the Quaternary.

\section{Maewo and Pentecost Islands}

Macfarlane et al. (1988) suggest late Pliocene subsidence of Pentecost and Maewo islands accompanied by upward reef growth and atoll development on Pentecost (Fig. 1). During the late Quaternary $(\sim 0.5 \mathrm{Ma})$, Pentecost and Maewo islands began their most recent phase of uplift at roughly the same time as eastern Espiritu Santo and Malakula islands. Relying on Mallick and Neef (1974) and Carney (1986), Macfarlane et al. (1988) concluded that Maewo and Pentecost islands have risen nearly 1000 masl during the past 500 k.y.

\section{Pentecost Island}

The highest points on Pentecost (maximum elevation of 946 m) expose Pliocene to Pleistocene coral reef limestone. Mallick and Neef (1974) mapped coral reef terraces as high as 340 $\mathrm{m}$ and concluded that these limestones record a period of 
subsidence starting at about 2.9 Ma followed by uplift since $\sim 500 \mathrm{Ka}$. They proposed mean uplift rates of $2.73 \mathrm{~mm} / \mathrm{yr}$ for central Pentecost Island since $500 \mathrm{Ka}$ and an accelerated Holocene uplift rate of $3.2 \mathrm{~mm} / \mathrm{yr}$. The mean uplift rate of 2.73 $\mathrm{mm} / \mathrm{yr}$ for the higher terraces is based only on a correlation with the Huon Peninsula reef terraces of northeast New Guinea (Chappell, 1974). No isotopic ages exist to support this correlation. Likewise, the Holocene uplift rate is inferred by correlation of the four lowest small terrace levels $(2,4-4.5,7$, and 15 masl) with Ward's (1971) $0.75-, 1.5-, 3.0-$, and 4.7-Ka highstands of Holocene sea level. There is no reasonable basis for these correlations or the inferred uplift rate. A sample of emerged coral from a remnant of emerged coral reef at about $2 \mathrm{~m}$ above living coral on the western coast gave a ${ }^{14} \mathrm{C}$ age of $6.860 \pm 0.110 \mathrm{Ka}$ (Taylor, unpubl. data). This sample indicates an uplift rate of $\leq 0.5 \mathrm{~mm} / \mathrm{yr}$, although faster uplift rates may be documented by additional study. However, despite a thorough search of the west coast I found no sign of possible Holocene emergence at heights of 10 to 20 masl as implied by uplift rates of 2 to $3 \mathrm{~mm} / \mathrm{yr}$.

A recent emergence event of approximately $10 \mathrm{~cm}$ in 1966-1968 occurred at approximately the same time as uplift of southern Espiritu Santo and northern Malakula Islands, which apparently was associated with a large shallow earthquake in August $1965\left(\mathrm{M}_{\mathrm{s}} \sim 7.5\right)$ (Taylor et al., 1987). The interval between the last two major coseismic uplifts of northern Malakula Island is 236 yr (Taylor et al., 1990). Assuming that the uplift is permanent, $10 \mathrm{~cm}$ of uplift every 236 years would produce a mean uplift rate of $0.42 \mathrm{~mm} / \mathrm{yr}$, consistent with the mean Holocene uplift rate indicated by the above-mentioned dated Holocene sample from Pentecost.

\section{Maewo Island}

As on Pentecost Island, much of Maewo Island is capped by coral reef limestone reaching a maximum altitude of about 811 masl. On northern Maewo Island, up to nine terraces occur from just above sea level to 780 masl; these dip gently to the west (Carney, 1986).

Carney (1986) found brief emergence and $15^{\circ}-20^{\circ}$ of westerly tilt of Maewo beginning at about $3 \mathrm{Ma}$. Furthermore, he proposed that the final emergence of Maewo occurred since approximately $500 \mathrm{Ka}$. Carney (1986) mapped a "recent raised reef" at 3 masl on the west coast of Maewo Island-a reefal deposit-also considered by Taylor et al. (1987) to be Holocene on the basis of excellent preservation of coral fabric. No isotopic age data support these estimates. If Holocene, this reefal deposit suggests a minimum Holocene uplift rate of about $0.5 \mathrm{~mm} / \mathrm{yr}$, as on Pentecost Island. Living corals recorded $6 \pm 3 \mathrm{~cm}$ of emergence in 1974-1975, which is temporally associated with the December 1973 earthquake $\left(M_{s}\right.$ 7.5) and related coseismic uplift of northwest Espiritu Santo Island (Taylor et al.,1987; 1990). The next oldest uplift of northwest Espiritu Santo Island occurred in $1866 \pm 5 \mathrm{yr}$, or 107 yr earlier (Taylor et al. 1990). Assuming that the measured uplift of Maewo Island is permanent, $6 \mathrm{~cm}$ of uplift every 107 yr would result in a mean uplift rate of $\sim 0.56 \mathrm{~mm} / \mathrm{yr}$, similar to the mean uplift rate inferred from the Holocene coral reef terrace.

\section{DISCUSSION}

The late Quaternary $(<0.5 \mathrm{Ma})$ pattern of vertical movement based on coral reef terraces in the central New Hebrides Island Arc is straightforward: the Aoba Basin has been subsiding, whereas Malakula and Espiritu Santo islands (which are next to the plate boundary) and Pentecost and Maewo islands (in the backarc) have been uplifting. However, many questions remain:
1. When was the present geographic distribution of vertical deformation established? If the present pattern is related to subduction of the DEZ and WTM, a related question is: When did these two features begin to affect the tectonics of the central New Hebrides Island Arc?

2. To what extent was central New Hebrides Island Arc morphology already anomalous when the ongoing phase of vertical deformation-driven by subduction of the WTM and DEZ - was initiated?

3. What was the state of the inner trench slope when the DEZ and WTM began to subduct?

4. What is the relationship between earthquakes and vertical deformation of the frontal arc, volcanic arc, and backarc?

Most workers agree that subduction of the DEZ and WTM is the main cause of the Quaternary pulse of vertical deformation in the central New Hebrides Island Arc, although the timing and total amount of uplift are not known in sufficient detail. In the absence of a better model, I assume that the trends of the subducted parts of the DEZ and WTM are similar to their unsubducted parts and that the rate of plate convergence is $\sim 10 \mathrm{~cm} / \mathrm{yr}$ (DeMets et al., 1990) in a direction of $\mathrm{N} 76^{\circ} \mathrm{E} \pm 11^{\circ}$ (Pascal et al., 1978; Isacks et al., 1981). The trend of the WTM suggests that it intersects and terminates against the DEZ. The trend of the DEZ and the convergence direction require that the intersection of the DEZ with the New Hebrides Island Arc migrates northward at a rate of about 2.5 cm/yr (Taylor et al. 1980; Collot et al., 1985). The DEZ may have been subducting at the New Hebrides Island Arc since approximately 2-3 Ma (Marthelot et al., 1985; Louat et al., 1988). Thus, at 2-3 Ma, the DEZ may have been subducting at a point approximately $50-75 \mathrm{~km}$ south of its present location. If the southern part of the DEZ is presently subducting beneath northern Malakula Island, then at 2-3 Ma it may have been subducting beneath southern Malakula, which may have been uplifting as northern Malakula Island is today. However, this analysis does not take into account the possibility that backarc basin spreading on the North Fiji Plateau may add several centimeters per year to the $\sim 10 \mathrm{~cm} / \mathrm{yr}$ of Australia-India/Pacific plate relative motion at the central New Hebrides Island Arc, and that the migration rate may be faster than $2.5 \mathrm{~cm} / \mathrm{yr}$.

However, before $300-400 \mathrm{Ka}$ on northern Malakula Island there is no evidence of uplift caused by subduction of the DEZ. Collot and Fisher (1989) attributed uplift of the northern Malakula reef terraces to subduction of a seamount on the southern half of the DEZ. Given a convergence rate of 10 $\mathrm{cm} / \mathrm{yr}$, this uplift history is consistent with the timing of uplift implied by subduction of a seamount on the south flank of the DEZ and a reentrant on the inner trench slope. However, the absence of evidence of uplift before $500 \mathrm{Ka}$ suggests a gap in the uplift history between about $500 \mathrm{Ka}$ and $2.0 \mathrm{Ma}$, when the northern part of the DEZ might have been migrating past northern Malakula Island at $2.5 \mathrm{~cm} / \mathrm{yr}$.

Unfortunately, poor biostratigraphic resolution makes it difficult to determine details of the Quaternary tectonic history in the age range older than that recorded by coral reef terraces ( $>300 \mathrm{Ka}$ ). Moreover, application of uranium-series dating of corals from the central New Hebrides Island Arc is limited to the past $125 \mathrm{k} . \mathrm{y}$. because the wet climate has promoted the diagenetic alteration of older corals, making them unsuitable for this type of dating.

Collot et al. (1985) and Macfarlane et al. (1988) proposed that uplift of the backarc and frontal arc occurred simultaneously with subsidence of the Aoba Basin. This synchroneity is supported by the ages of uplifted reef terraces. The timing of coral emergence strongly supports a close mechanical rela- 
tionship between coseismic uplift of the frontal-arc islands of Espiritu Santo and Malakula and the backarc islands of Pentecost and Maewo and subsidence of Aoba Island (Taylor et al., 1987). Such coseismic uplift of a zone in the backarc was reported to have accompanied the great 1960 earthquake in Chile and the 1964 earthquake in Alaska (Plafker, 1972).

With one possible exception, the uplift histories of the central New Hebrides Island Arc, inferred from both general stratigraphy and emerged coral reefs, are similar. The elevation of coral reefs suggests that the amount of uplift of western Espiritu Santo Island during the ongoing episode may be much greater than previously recognized. Presently, only about 400 $\mathrm{m}$ of late Quaternary uplift of western Espiritu Santo Island is absolutely required by the presence of emerged coral reefs. Apparently the idea that the western part of the island had uplifted less than the eastern part originated with the observation that coral limestone extends to nearly 800 masl on eastern Espiritu Santo but to only 400 masl on western Espiritu Santo Island (Mallick and Greenbaum, 1977a). If western Espiritu Santo Island had risen from the sea during the late Quaternary then it seemed that it should also have a coral cap. However, it is unlikely that coral limestone formed at levels higher than $400 \mathrm{~m}$ on western Espiritu Santo Island because of several reasons:

1. All of western Espiritu Santo Island has uplifted at least 200-400 m, but coral limestone was deposited only on small areas on the northern and southern ends where the environmentally detrimental effects of island-derived terrigenous sediment is minimal. Coral reefs were unable to form elsewhere during the most recent $400 \mathrm{~m}$ of uplift because of the steep slopes and sediment. It is also reasonable to assume that corals may not have been able to establish themselves during previous uplifts either.

2. A very rapidly uplifting island, such as western Espiritu Santo Island, can be disadvantageous for coral reef deposition, a fact not realized by previous workers. The faster the uplift rate, the greater the vertical extent of emerged shoreline over which the limestone produced by a shallow fringing reef must spread. For example, at uplift rates of $6 \mathrm{~mm} / \mathrm{yr}$, the past $100-\mathrm{k} . \mathrm{y}$. of limestone production would have to form a continuous layer to an altitude of $600 \mathrm{~m}$. If the uplift rate were only $3 \mathrm{~mm} / \mathrm{yr}$ the limestone would have to cover the land to an altitude of only $300 \mathrm{~m}$ and the layer could be twice as thick.

3. The emerged coral limestone, extending 400 masl on the northern and southern ends of western Espiritu Santo, was deposited on areas of gently sloping substrate. These gently sloping areas provided relatively large areas of water shallower than $30 \mathrm{~m}$, a water depth of maximum coral limestone production. There are no other gently sloping areas on the western part of the island where coral reefs could have produced significant amounts of coral limestone during earlier phases of the uplift. The steepness of all areas higher than 400 masl does not provide a suitable substrate on which coral reefs could have become established, even if shedding of terrigenous sediment was unimportant. Thus, the surface area in the depth range of $0-30 \mathrm{~m}$ on a steeply sloping substrate is so limited that total reef carbonate production by organisms clinging to the slope would be insignificant.

Alternatively, I propose a hypothesis that the tectonic relationship between eastern and western Espiritu Santo Island is demonstrated by reef emergence during the past 125 k.y. Espiritu Santo Island has risen and tilted eastward in the same pattern shown by the Holocene and 125 -Ka reef terraces (Fig. 4). Therefore, uplift rates on the western part have been twice as rapid as on the eastern part for at least $125 \mathrm{Ka}$. The
$125-\mathrm{Ka}$ and younger reef terraces occur continuously across the southern coast of Espiritu Santo Island and clearly demonstrate this relationship (Figs. 2 and 4). If I extrapolate back in time, the question becomes how far back in time the relationship existed and whether all of the anomalous morphology of the central New Hebrides Island Arc can be attributed to the ongoing phase of uplift due to subduction of the DEZ and WTM.

Given that western Espiritu Santo Island has uplifted about twice as rapidly as eastern Espiritu Santo, the paleo-shorelines of reef terraces from the eastern to western parts can be projected. For example, the Mount Tankara coral reef at 784 masl should occur at about 1300-1400 masl on western Espiritu Santo. At the mean uplift rate of the past 125 k.y., the $1400 \mathrm{~m}$ of emergence would have occurred in only $350-400$ $\mathrm{Ka}$. If this process is extrapolated further into the past, western Espiritu Santo Island would have begun to emerge at approximately $500 \mathrm{Ka}$. Prior to that time, if I assume that the central New Hebrides Island Arc once had an arc-trench morphology similar to the area north of Espiritu Santo Island (Fig. 1), western Espiritu Santo Island would have occupied a location equivalent to the inner trench slope at a depth of about $4,000 \mathrm{~m}$. At the uplift rate of the past $125 \mathrm{k} . \mathrm{y}$. (3.2 $\mathrm{mm} / \mathrm{yr}$ ), such an inner trench slope would have reached the altitudes of the peaks of western Espiritu Santo Island in approximately $2 \mathrm{~m}$.y. In contrast, at the Holocene uplift rate of $6 \mathrm{~mm} / \mathrm{yr}$ this would require only $1 \mathrm{~m} . \mathrm{y}$.

The proposed Pliocene to Pleistocene timing of transgression and uplift on Malakula Island was determined by the assumption that the Malua and Wintua formations are Pliocene or early Pleistocene in age (Mitchell, 1966, 1971; Macfarlane et al., 1988). Perhaps the lower parts of these formations were deposited as the island subsided. However, the upper parts of these formations may represent shallowingupward, regressive deposits analogous to distal forereef deposits offshore from the modern coral reef. Because the age of the coral limestone on the highest points of northern Malakula Island is probably less than $400 \mathrm{Ka}$, at least the upper part of the underlying Malua Formation may be late Quaternary in age.

In contrast to northern Malakula Island, the primary episode of uplift, which raised coral limestone to 874 masl on the southern part of the island, ceased sometime in the past and only local minor uplift continues. Until the ages of the higher coral limestones of southern Malakula Island or the underlying Wintua Formation are better known, we cannot accurately evaluate the timing of this earlier primary phase of uplift.

Taylor et al. (1985) noted that both northern Malakula and Espiritu Santo islands have dual topographic axes trending north-northwest-south-southeast on Espiritu Santo Island and northwest-southeast on northern Malakula Island. The eastern Espiritu Santo plateaus and northeast Malakula are in a position similar to that of the Torres Islands farther north in the New Hebrides Island Arc, between the plate boundary and volcanic arc. The Torres Islands are assumed to be emergent because the topographic axis they occupy has been the axis of most rapid uplift rate. By analogy, the topographic axes of eastern Espiritu Santo and northeast northern Malakula also are assumed to have once occupied the axes of most rapid uplift rate. By approximately $500 \mathrm{Ka}$, new axes of much more rapid uplift developed beneath western Espiritu Santo and southwest northern Malakula. The rapid uplift caused new dominant topographic axes to develop on western Espiritu Santo and southwest northern Malakula. It seems likely that if the present geographic distribution of vertical deformation and the axes of maximum uplift rate result from subduction of the DEZ and WTM, then the westward shift of 
these axes may coincide with the initiation of the subduction effects of the DEZ and WTM.

The most plausible scenario is that the most recent phase of uplift of the central New Hebrides Island Arc began during the early Quaternary with the initiation of subduction of the DEZ beneath Malakula Island. If it migrated northward at 2.5 $\mathrm{cm} / \mathrm{yr}$, its effects migrated northward at the same rate. At roughly $1 \mathrm{Ma}$, the DEZ began to influence the uplift of southern Espiritu Santo Island. The WTM also began to be subducted by about $500 \mathrm{Ka}$ and caused the westward shift of the uplift axis which affects northern Espiritu Santo Island even where the DEZ has not been subducted. The WTM accounts for the beginning of uplift of western Espiritu Santo Island. This uplift pattern is demonstrated by the uplift of northwest Espiritu Santo where only the WTM is presently subducting. As the DEZ has migrated northward along the west coast of Espiritu Santo, its effects have been superimposed upon those of the WTM and it has intensified the deformation of the adjacent part of the arc (e.g., Collot et al., 1985; Fisher et al., 1986; Greene et al., 1988; Collot and Fisher, 1991; Fisher et al., 1991). This is happening now directly inland from the intersection of the DEZ with Espiritu Santo Island. The timing of vertical deformation and the temporal relationship between coseismic uplift of southern Malakula and Espiritu Santo islands and between Maewo and Pentecost islands support the idea that Aoba Basin subsidence and backarc uplift are also a direct result of subduction of the WTM and DEZ.

\section{CONCLUSIONS}

The late Quaternary vertical tectonic history of the central New Hebrides Island Arc is characterized by at least hundreds of meters of uplift of the frontal and backarcs and similar subsidence of the volcanic arc. Coral emergence data indicate that vertical deformation from frontal to backarcs is directly related to large, shallow earthquakes on the interplate thrust zone. However, the late Quaternary tectonic history is based mainly on uplifted coral reef terraces that represent the past few hundred thousand years of tectonism. This detailed history does not extend back to the earlier Quaternary when the ongoing pattern of vertical deformation may have begun. Nevertheless, the late Quaternary history suggests that the present pattern and rates of vertical deformation should be extrapolated back to at least $1 \mathrm{Ma}$ or longer. If this is the case, then the total amount of structural and morphological modification of the arc during the ongoing phase of deformation is much more significant than has been previously assumed and the morphology of the central New Hebrides Island Arc may have resembled a more typical arc-trench area like that north of Espiritu Santo Island only 1-2 Ma. In this model, subduction of the WTM and DEZ initiated the ongoing episode of vertical deformation. This raises the question as to whether subduction of such ridges causes relatively superficial tectonic modification of an arc or whether the effects are quite profound. This paper proposes that virtually all of the anomalous morphology of the central New Hebrides Island Arc results from the subduction of the DEZ and WTM.

\section{ACKNOWLEDGMENTS}

I wish to thank the numerous citizens of Vanuatu, the British Geological Survey, and ORSTOM (Institut Français de Recherche Scientifique pour le Développement en Coopération), who facilitated the fieldwork that provides the basis of this report. This paper was encouraged by stimulating discussions with the co-chief scientists and fellow scientific participants on Leg 134. I gratefully acknowledge the support of these individuals and the Ocean Drilling Program. Research leading to this paper was supported by TAMRF PO\# 20473, NSF Grants EAR 79-19912, EAR-8507983, EAR-8904987, and ATM-8922114 to the University of Texas at Austin, EAR-7815188 to Cornell University, the government of Vanuatu, and ORSTOM. This is University of Texas at Austin Institute for Geophysics contribution 884 .

\section{REFERENCES}

Bloom, A. L., Broecker, W. S., Chappell, J. M. A., Matthews, R. K., and Mesolella, K. J., 1974. Quaternary sea-level fluctuations on a tectonic coast: new ${ }^{230} \mathrm{Th} /{ }^{234} \mathrm{U}$ dates from the Huon Peninsula, New Guinea. Quat. Res., 4:185-205.

Bloom, A. L., and Yonekura, N., 1985. Coastal terraces generated by sea-level change and tectonic uplift. In Woldenberg, M. J. (Ed.), Models in Geomorphology: Winchester, MA (Allen and Unwin), 139-153.

Carney, J. N., 1986. Geology of Maewo. Regional Rept.-Vanuatu Dep. Geol., Mines and Rural Water Supplies.

Carney, J. N., and Macfarlane, A., 1982. Geological evidence bearing on the Miocene to Recent structural evolution of the New Hebrides Arc. Tectonophysics, 87:147-175.

Chappell, J.M.A., 1974. Geology of coral terraces, Huon Peninsula, New Guinea: a study of Quaternary tectonic movements and sea level changes. Geol. Soc. Am. Bull., 89:356-368.

Chatelain, J.-L., Isacks, B. L., Cardwell, R. K., Prevot, R., and Bevis, M., 1986. Patterns of seismicity associated with asperities in the central New Hebrides island arc. J. Geophys. Res., 91:12497-12519.

Chung, W. Y., and Kanamori, H., 1978. A mechanical model for plate deformation associated with aseismic ridge subduction in the New Hebrides arc. Tectonophysics, 50:29-40.

Collot, J.-Y., Daniel, J., and Burne, R. V., 1985. Recent tectonics associated with the subduction/collision of the D'Entrecasteaux zone in the central New Hebrides. Tectonophysics, 112:325-356.

Collot, J.-Y., and Fisher, M. A., 1988. Crustal structure from gravity data of a collision zone in the central New Hebrides Island Arc. In Greene, H. G., and Wong, F. L. (Eds.), Geology and Offshore Resources of Pacific Island Arcs - Vanuatu Region. Circum-Pac. Counc. Energy and Miner. Resour., Earth Sci. Ser., 8:125-139. 1989. Formation of forearc basins by collision between seamounts and accretionary wedges: an example from the New Hebrides subduction zone. Geology, 17:930-933.

1991. The collision zone between the North d'Entrecasteaux Ridge and the New Hebrides Island Arc. Part 1: Seabeam morphology and shallow structure. J. Geophys. Res., 96:4457-4478.

DeMets, C., Gordon, R. G., Argus, D. F., and Stein, S., 1990. Current plate motions. Geophys. J. Int., 101:425-478.

Ebel, J. E., 1980. Source processes of the 1965 New Hebrides Islands earthquakes inferred from teleseismic wave forms. Geophys. J. $R$. Astron. Soc., 63:381-403.

Fisher, M. A., Collot, J.-Y., and Geist, E. L., 1991. The collision zone between the north d'Entrecasteaux ridge and the New Hebrides island arc. Part 2: structure from multichannel seismic data. $J$. Geophys. Res., 96:4479-4495.

Fisher, M. A., Collot, J.-Y., and Smith, G. L., 1986. Possible causes for structural variation where the New Hebrides island arc and the D'Entrecasteaux zone collide. Geology, 14:951-954.

Gilpin, L. M., 1982. Tectonic geomorphology of Santo Island, Vanuatu (New Hebrides) [M.S. thesis]. Cornell Univ., Ithaca, NY.

Greene, H. G., Macfarlane, A., Johnson, D. A., and Crawford, A. J., 1988. Structure and tectonics of the central New Hebrides Arc. In Greene, H. G., and Wong, F. L. (Eds.), Geology and Offshore Resources of Pacific Island Arcs-Vanuatu Region. Circum-Pac. Counc. Energy and Miner. Resour., Earth Sci. Ser., 8:377-412.

Isacks, B. L., Cardwell, R. K., Chatelain, J. L., Barazangi, M., Marthelot, J.-M., Chinn, D., and Louat, R., 1981. Seismicity and tectonics of the central New Hebrides island arc. In Simpson, D. W., and Richards, P. G. (Eds.), Earthquake Prediction: An International Review. Am. Geophys. Union, Maurice Ewing Ser., 4:93-116.

Jouannic, C., Taylor, F. W., Bloom, A. L., 1982. Sur la surrection et la deformation d'un arc jeune: l'arc des Nouvelles Hebrides. Trav. Doc. ORSTOM, 147:223-246. 
Jouannic, C., Taylor, F. W., Bloom, A. L., and Bernat, M., 1980. Late Quaternary uplift history from emerged reef terraces on Santo and Malekula Islands, central New Hebrides island arc. Tech. Bull.U.N. Econ. Soc. Comm. Asia Pac., CCOP/SOPAC, 3:91-108.

Louat, R., Hamburger, M., and Monzier, M., 1988. Shallow and intermediate-depth seismicity in the New Hebrides Arc: constraints on the subduction process. In Greene, H. G., and Wong, F. L. (Eds.), Geology and Offshore Resources of Pacific Island Arcs-Vanuatu Region. Circum-Pac. Counc. Energy and Miner. Resour., Earth Sci. Ser., 8:329-356.

Macfarlane, A., Carney, J. N., Crawford, A. J., and Greene, H. G., 1988. Vanuatu-a review of the onshore geology. In Greene, H. G., and Wong, F. L. (Eds.), Geology and Offshore Resources of Pacific Island Arcs-Vanuatu Region. Circum-Pac. Counc. Energy and Miner. Resour., Earth Sci. Ser., 8:45-92.

Mallick, D. I. J., and Ash, R. P., 1975. Geology of the Southern Banks Islands. Regional Rept.-New Hebrides Geol. Surv.

Mallick, D. I. J., and Greenbaum, D., 1977a. Geology of Southern Santo. Regional Rept.-New Hebrides Geol. Surv. 1977b. Geology of South Santo. New Hebrides Geol. Surv., Sheet 4. 1:100,000.

Mallick, D.I.J., and Neef, G., 1974. Geology of Pentecost. Regional Rept.-New Hebrides Geol. Surv.

Marthelot, J.-M., Chatelain, J. L., Isacks, B. L., Cardwell, R. K., and Coudert, E., 1985. Seismicity and attenuation in the central Vanuatu (New Hebrides) islands: a new interpretation of the effect of subduction of the d'Entrecasteaux fracture zone. J. Geophys. Res., 90:8641-8650.

Mitchell, A.H.G., 1966. Geology of South Malekula. Regional Rept.-New Hebrides Geol. Surv., No. 3. New Hebrides Geol. Surv.

Neef, G., and Veeh, H. H., 1977. Uranium series ages and late Quaternary uplift in the New Hebrides. Nature, 269:682-683.

Paltech Proprietary, Ltd., 1979. Age and environmental determinations of six samples from Maewo and Santo Islands, New Hebrides. Report 1979/17 to New Hebrides Geol. Surv., Occ. 1/79.
Pascal, G., Isacks, B. L., Barazangi, M., and Dubois, J., 1978. Precise relocations of earthquakes, and seismotectonics of the New Hebrides island arc. J. Geophys. Res., 83:4957-4973.

Plafker, G., 1972. Alaskan earthquake of 1965 and Chilean earthquake of 1960: implications for arc tectonics. J. Geophys. Res., 77:901925.

Ravenne, C., Pascal, G., Dubois, J., Dugas, F., and Montadert, L., 1977. Model of young intra-oceanic arc: the New Hebrides island arc. In Int. Symp. on Geodynamics in South-west Pacific, Noumea, New Caledonia, 1976. Paris (Editions Technip), 63-78.

Taylor, F. W., Edwards, R. L., Wasserburg, G. J., and Frohlich, C., 1990. Seismic recurrence intervals and timing of aseismic subduction inferred from emerged corals and reefs of the central Vanuatu (New Hebrides) frontal arc. J. Geophys. Res., 95:393-408.

Taylor, F. W., Frohlich, C., Lecolle, J, and Strecker, M., 1987. Analysis of partially emerged corals and reef terraces in the central Vanuatu arc: comparison of contemporary coseismic and nonseismic with Quaternary vertical movements. J. Geophys. Res., 92:4905-4933.

Taylor, F. W., Isacks, B. L., Jouannic, C., Bloom, A. L., and Dubois, J., 1980. Coseismic and Quaternary vertical tectonic movements, Santo and Malekula Islands, New Hebrides island arc. J. Geophys. Res., 85:5367-5381.

Taylor, F. W., Jouannic, C., and Bloom, A. L., 1985. Quaternary uplift of the Torres Islands, northern New Hebrides frontal arc: comparison with Santo and Malekula Islands, central New Hebrides frontal arc. J. Geol., 93:419-438.

Urmos, J., 1985. Oxygen isotopes, sea levels, and uplift of reef terraces, Araki Island, Vanuatu [M.S. thesis]. Cornell Univ., Ithaca, NY.

Ward, W. T., 1971. Postglacial changes in level of land and sea. Geol. Mijnbouw, 50:703-718.

Ms 134A-103 